\title{
Thermal response of broilers in different poultry house models at the Amazon environmental conditions
}

\author{
Resposta térmica de frangos de corte em diferentes modelos de aviário nas \\ condições climáticas da Amazônia
}

\author{
João Paulo Ferreira Rufino (D) ${ }^{1 *}$, Lucieta Guerrero Martorano (iD) ${ }^{2}$ \\ ${ }^{1}$ Faculdade de Ciências Agrárias, Universidade Federal do Amazonas (UFAM), Manaus, AM, Brazil \\ 2 EMBRAPA Amazônia Oriental-NAPT, Santarém, PA, Brazil
}

\begin{abstract}
The present study aimed to evaluate the thermal response of two models of aviary installed in different conditions of the Amazon rainforest and its effects on the poultry welfare. Two models of aviary were evaluated: conventional model, used in the Eastern Amazon (forced ventilation, low ceiling height, little vegetation around the aviary, and high density of birds per $\mathrm{m}^{2}$ ), and alternative model, used in the Western Amazon (natural ventilation, high ceiling height, a lot of vegetation around the aviary, and average density of birds per $\mathrm{m}^{2}$ ). Data collected were subjected to a Tukey test $(p \leq 0.05)$ after a significant ANOVA result. The conventional model of poultry house presented higher $(p<0.05)$ heat accumulation in its structures. Birds housed in the conventional model of poultry house had higher $(p<0.05)$ head, neck, back and leg temperatures, higher $(p<0.05)$ body heat accumulation, and lower heat exchange efficiency to the environment. From these results, we conclude that under
\end{abstract}

* Corresponding author: joaopaulorufino@live.com

Received: 2020 Aug 14 | Approved: 2020 Oct 22
Amazonian environmental conditions, the alternative model of poultry house, with natural ventilation, higher height of ceiling and vegetation around the poultry house, provided better environmental conditions and thermal comfort to the broilers due to lower heat concentration and better possibility of heat exchange with the environment.

Keywords: Amazon rainforest. Animal behavior. Animal welfare. Gallus gallus domesticus. Poultry.

\section{Resumo}

O presente estudo teve como objetivo avaliar a resposta térmica de dois modelos aviários instalados em diferentes condições da Amazônia e seus efeitos no bem-estar das aves. Foram avaliados dois modelos de aviário para 
alojamento dos frangos de corte: modelo convencional (ventilação forçada, teto baixo, pouca vegetação ao redor do aviário e alta densidade de aves) e modelo alternativo (ventilação natural, teto alto, muita vegetação ao redor do aviário e baixa densidade de aves). Os dados coletados foram submetidos ao teste de Tukey $(p \leq 0,05)$ após um resultado significativo da ANOVA. O aviário de modelo convencional apresentou maior $(p<0,05)$ acúmulo de calor em suas estruturas. As aves alojadas no aviário de modelo convencional apresentaram temperaturas mais altas $(p<0,05)$ na cabeça, pescoço, dorso e patas, maior $(p<0,05)$ acúmulo de calor corporal e menor eficiência na troca de calor com o ambiente. Diante destes resultados, concluiu-se que, nas condições climáticas da Amazônia, o modelo de aviário alternativo, com ventilação natural, maior altura do teto e vegetação em seu entorno, proporcionou melhores condições ambientais e conforto térmico para frangos de corte em confinamento devido a menor concentração de calor corporal e maior possibilidade de troca de calor com o ambiente.

Palavras-chave: Amazônia. Comportamento animal. Bemestar animal. Gallus gallus domesticus. Avicultura.

\section{Introduction}

In animal welfare, the environment is characterized by the interaction between physical and biological factors, and how they directly influence the animals performance (Bueno and Rossi, 2006). Contextually, the main obstacles related to animal welfare are associated with the microclimate that is controlled direct and indirectly in the facilities (Tinôco, 2001). These factors cause effects on animal production at all stages, which may cause a reduction on performance and significant economic losses (Nääs et al., 2007).

Abreu and Abreu (2011), studying heat stress in birds, indicated that $80 \%$ of the energy ingested is used to maintain the homeothermia, and only $20 \%$ is directed to the production. However, comparing his results with those of Silva and Vieira (2010), we observed that homeostasis mechanism is efficient only when the environmental conditions is within certain limits. Therefore it is important that aviaries maintain environmental temperatures according to the comfort conditions to the birds.

The comfort zone for birds can be defined as the ambient temperature range where the metabolic rate is minimal and homeothermia is maintained with less energy expenditure (Nascimento et al., 2014). The birds' ability to dissipate heat decreases as the temperature and relative humidity of the environment leave the thermoneutral zone (air temperature at $24^{\circ} \mathrm{C} / 75.2^{\circ} \mathrm{F}$ and $70 \%$ relative humidity). Any heat evaporative loss may cause problems in animal welfare due to the reduction on maintenance energy, and compromise the body development (Abreu e Abreu, 2011; Lopes et al., 2015).

In this sense, poultry production in the Amazon rainforestfaces a considerable number of difficulties to obtain great performance results, especially due to the constant need to meet environmental conditions that allow animals to express their maximum productive potential (Cruz et al., 2016). Broilers are physiologically homeothermic animals and directly feel the influence of climates outside their comfort zone, causing a direct effect on their metabolism and production (meat or eggs) (Kolb, 1984; Cunningham, 2004). Considering the above, this study aimed to evaluate the thermal response of two models of aviary installed in different conditions of the Amazon rainforest and its effects on the poultry welfare.

\section{Material and methods}

The experimental procedures followed the guidelines established by the Ethics Committee on the Use of Animals at the Universidade Federal do Amazonas (UFAM). In this study, two models of aviary in different conditions were evaluated: conventional model, used in the Eastern Amazon (forced ventilation, low ceiling height, little vegetation around the aviary, and high density of birds per $\mathrm{m}^{2}$ ), and alternative model, used in the Western Amazon (natural ventilation, high ceiling height, a lot of vegetation around the aviary, and average density of birds per $\mathrm{m}^{2}$ ).

The conventional model, installed in Santarém city, Pará, Brazil (latitude $3^{\circ} 06^{\prime} 14^{\prime \prime}$ S, longitude $59^{\circ}$ 
$58^{\prime} 46^{\prime \prime} \mathrm{W}$ and altitude of $92 \mathrm{~m}$ ), presented forced ventilation, dimensions of $50 \times 6$ meters and ceiling height of $2.50 \mathrm{~m}$, without internal partitions, cement tiles, artificial lighting, and curtain system. The aviary floor was covered with $10 \mathrm{~cm}$ of sawdust. There was little vegetation around the aviary, presenting only a few trees. The climate was classified as tropical with an average annual precipitation of $2,282 \mathrm{~mm}$, and temperature ranging from 22 to $28{ }^{\circ} \mathrm{C}$. The birds were housed at a density of 22 birds $/ \mathrm{m}^{2}$, with controlled feed and water ad libitum, being managed according to the strain handbook.

The alternative model, installed in Manaus city, Amazonas, Brazil (latitude $3^{\circ} 06^{\prime} 14^{\prime \prime} \mathrm{S}$, longitude $59^{\circ} 58^{\prime} 46^{\prime \prime} \mathrm{W}$ and altitude of $92 \mathrm{~m}$ ), presented natural ventilation, dimensions of $25 \times 8$ meters, ceiling height of $3.25 \mathrm{~m}, 14$ internal partitions,
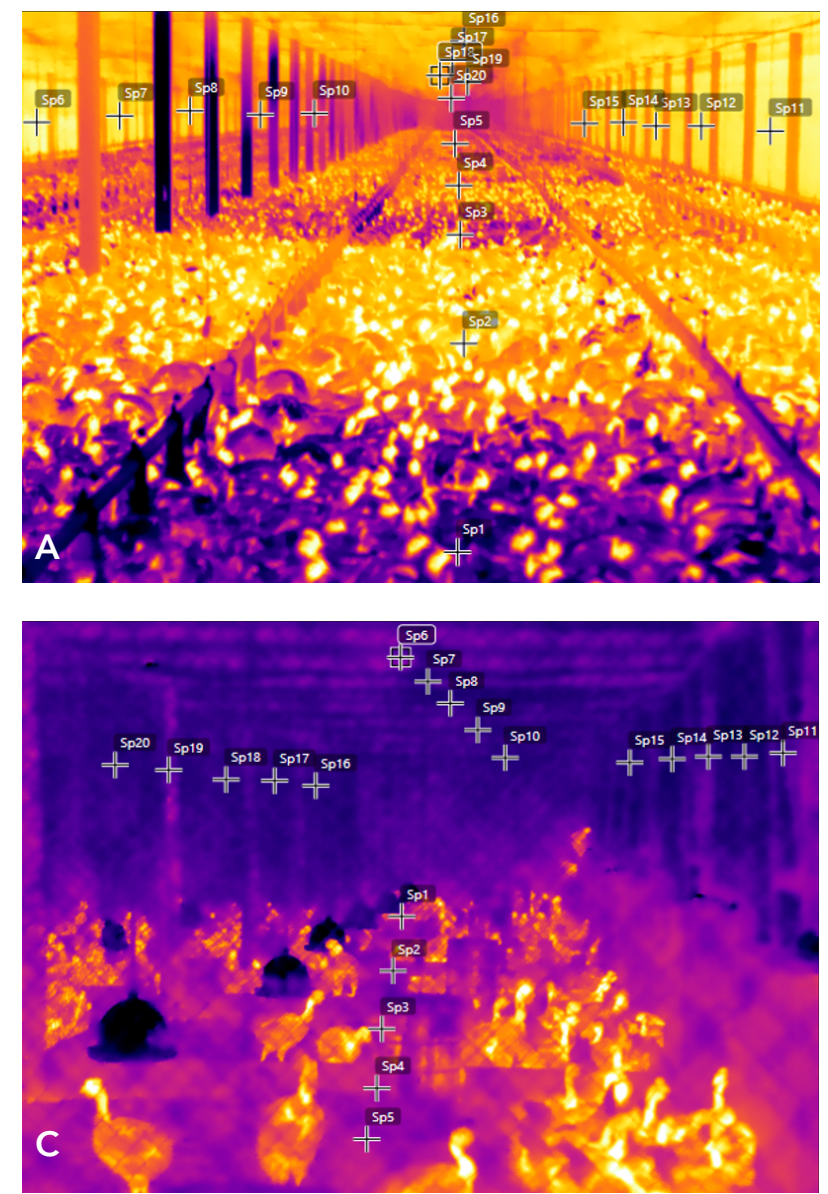

cement tiles, open lanterns for ventilation, natural lighting, and without curtain system. The aviary floor was covered with $10 \mathrm{~cm}$ of sawdust. The aviary had a lot of vegetation around it, being composed by trees and mixed vegetation. The climate was classified as humid tropical, with average annual precipitation of $2,286 \mathrm{~mm}$, and temperature ranging from 27 to $32{ }^{\circ} \mathrm{C}$. The birds were housed at a density of 12 birds $/ \mathrm{m}^{2}$, with controlled feed and water ad libitum, being managed according to the strain handbook.

Initially, thermal images were captured using a FLIR ${ }^{\circledR}$ infrared thermographic camera at 2 p.m., for two consecutive days. Two images of each aviary were recorded using different angles (Figure 1). Data were collected at five points in each aviary structure: ceiling, walls (right and left), and floor.
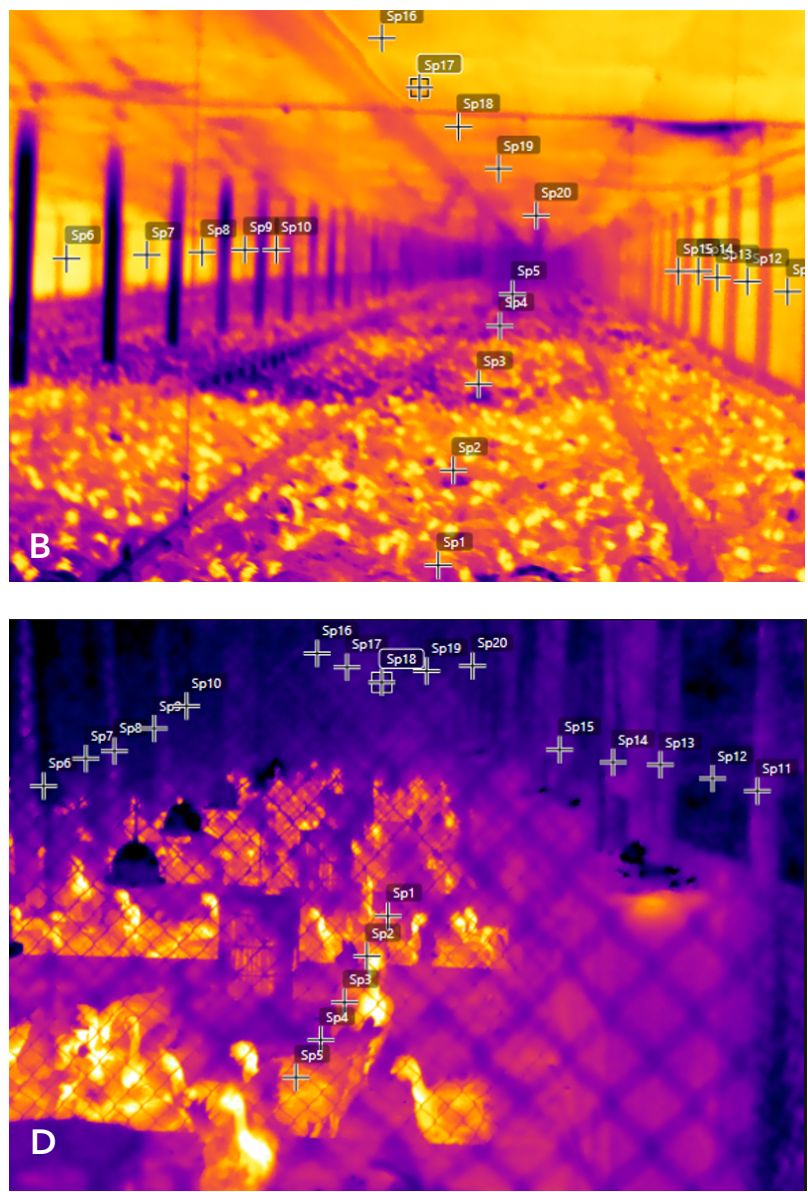

Figure 1 - Thermographic images of the conventional aviary (A: north direction; B: south direction) and alternative aviary (C: north direction; D: south direction). 
To evaluate the body surface thermal response, 30 broilers of each aviary model were randomly selected: 30-day-old Cobb 500 broilers in the conventional aviary, and 35-week-old Rhode Island Red broilers in the alternative aviary. From these thermographic pictures, the temperatures of the following targets were evaluated: (i) head, (ii) neck, (iii) back, and (iv) legs (Figures 2 and 3). To determine the thermal response, the temperature was assessed at five points for each target. Based on these results and on the analysis of the temperature of the wings, the average surface temperature (AST) of the birds was calculated according to the equation proposed by Richards (1971).

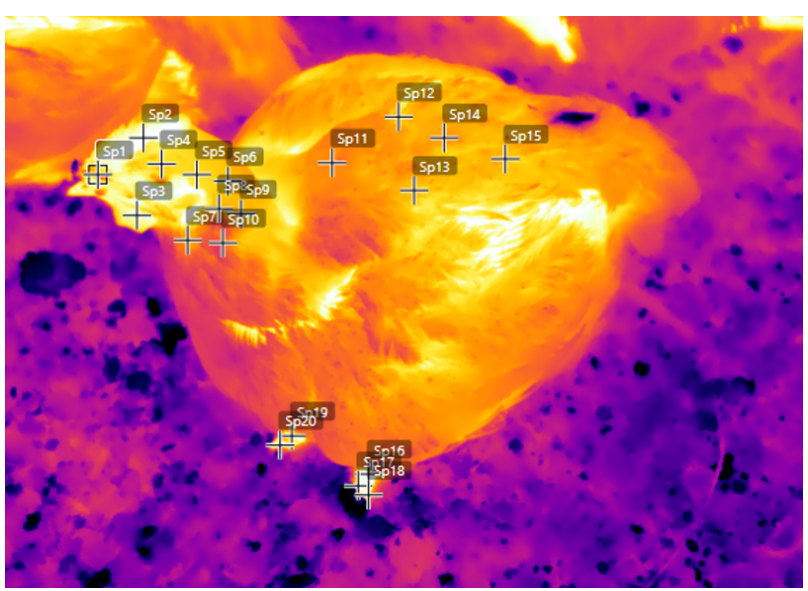

Figure 2 - Thermal picture of broiler managed in the conventional aviary.

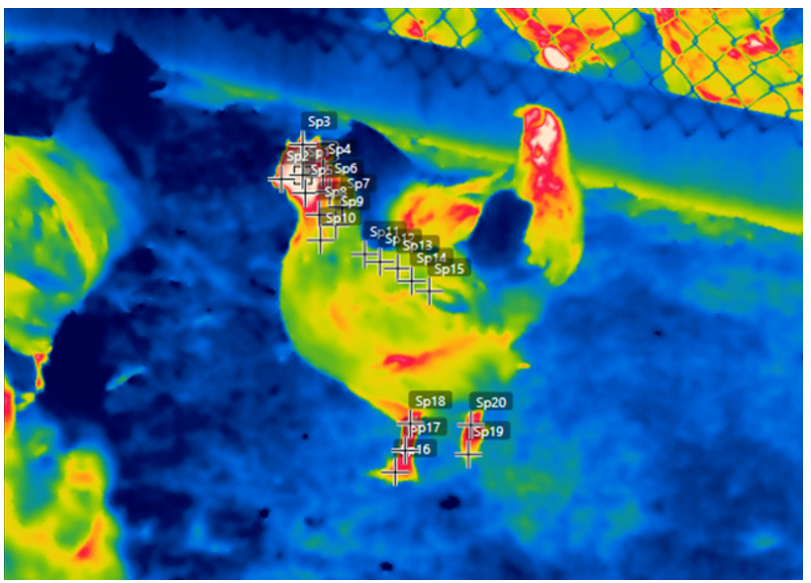

Figure 3 - Thermal picture of broiler managed in the alternative aviary.
All data collected in this study were analyzed using the GLM procedure of the SAS (Statistical Analysis System, v. 9.2), where the data of aviary models were submitted to ANOVA and, subsequently, compared by the Tukey test. The results were considered significant at $p \leq 0.05$.

\section{Results and discussion}

All internal structures in the aviaries presented significant results $(p<0.05)$, with the conventional aviary presenting greater heat accumulation in its structures than the alternative aviary (Table 1). It is important to mention that the aviaries presented different dimensions and different internal and external structures, being the conventional aviary planned according to the models observed in the Brazilian south region, while the alternative model was adapted to the Amazon environmental conditions, aiming to provide a better welfare condition for the birds.

Table 1 - Thermal response of different structures of two models of aviary installed in different conditions of the Amazon rainforest

\begin{tabular}{lcccc}
\hline \multirow{2}{*}{ Aviary model } & \multicolumn{4}{c}{ Variables $\left({ }^{\circ} \mathbf{C}\right)$} \\
\cline { 2 - 5 } & Roof & Right wall & Left wall & Floor \\
\hline Conventional & $37.60^{\mathrm{a}}$ & $39.06^{\mathrm{a}}$ & $38.96^{\mathrm{a}}$ & $37.56^{\mathrm{a}}$ \\
Alternative & $28.14^{\mathrm{b}}$ & $28.04^{\mathrm{b}}$ & $27.94^{\mathrm{b}}$ & $28.88^{\mathrm{b}}$ \\
p-value & $0.01^{\star}$ & $0.01^{\star}$ & $0.01^{\star}$ & $0.01^{\star}$ \\
CV (\%) & 2.73 & 1.44 & 2.79 & 4.30 \\
\hline
\end{tabular}

Note: $C V=$ coefficient of variation. ${ }^{*}$ Significant effect $(p \leq 0.01)$

According to Nääs et al. (2007), in several Brazilian regions, for economic reasons or lack of information, little importance has been given to the planning and architectural design of aviaries. The same authors also reported that the aviaries should be compatible with the climatic conditions of each region to provide an ideal environment. Each Brazilian region presents a unique environmental condition, which theoretically would impose that each region had an own model of aviary adapted 
to its conditions. However, in practice, it is common the use of the same model of aviary in all regions, regardless the climate condition and the animal welfare. As a consequence, in hot regions as the Amazon rainforest, the aviary tends to accumulate a lot of heat in their structures, especially in the summer, which provide a constant thermal discomfort to the birds, impairing its performance and carcass development.

Lavor et al. (2008) reported that the natural thermal control is a new tendence for the poultry industry due to the cost-benefit ratio, where there is no need to use mechanic equipment, and a significant emphasizes in the dimensions and type of material used to build the aviary, adapting its characteristics to those of the birds to create an ideal welfare condition.

These procedures aim to adapt the aviary according to the environment where it is built, providing to the birds better environmental conditions as it was verified in this study. The alternative aviary, despite not having forced ventilation and other features commonly used in conventional aviaries, had architectural dimensions that enabled greater dissipation of heat, providing a better environment for birds in the climatic conditions of the Amazon rainforest, where there is a natural predisposition for accumulation of environmental heat.

It was observed a significant effect $(p<0.05)$ of the aviary model on the thermal response of the birds, where the birds housed in the conventional aviary presented higher temperatures in head, neck, back and legs, which imply that the birds housed in the alternative aviary tend to present a better thermal comfort in the Amazon environmental conditions (Table 2).

It is a fact that the Amazon rainforest has unique environmental characteristics that stand out from other ecosystems found along Brazil's territory (Cavalcanti et al., 2009; Monteiro et al., 2014). However, these have been little studied as an influence factor in livestock, especially on the physiological aspect of the animals. The results founded in this study showed that birds housed in aviaries that used natural ventilation, a higher ceiling and vegetation around it presented better thermal comfort using the natural characteristics of the environment as a welfare factor, adapting the aviary to environmental conditions, and not the birds or the own environment, how it is suggested in the literature.

Table 2 - Thermal response of broilers housed in two models of aviary installed in different conditions of the Amazon rainforest

\begin{tabular}{lcccc}
\hline \multirow{2}{*}{ Aviary model } & \multicolumn{4}{c}{ Variables $\left({ }^{\circ} \mathbf{C}\right)$} \\
\cline { 2 - 5 } & Head & Neck & Back & Legs \\
\hline Conventional & $40.06^{\mathrm{a}}$ & $41.48^{\mathrm{a}}$ & $42.57^{\mathrm{a}}$ & $38.59^{\mathrm{a}}$ \\
Alternative & $39.68^{\mathrm{b}}$ & $36.45^{\mathrm{b}}$ & $32.34^{\mathrm{b}}$ & $32.84^{\mathrm{b}}$ \\
p-value & $0.03^{\star \star}$ & $0.01^{\star}$ & $0.01^{\star}$ & $0.01^{\star}$ \\
$\mathrm{CV}(\%)$ & 2.36 & 2.43 & 2.29 & 4.39 \\
\hline
\end{tabular}

Note: $C V=$ coefficient of variation. ${ }^{*}$ Significant effect $(p \leq 0.01)$. ** Significant effect $(p \leq 0.05)$.

The thermal control inside the aviaries is a challenge for the success of the poultry activity in regions where high temperatures occur most of the year, such as the Amazon region (Lavor et al., 2008). According to Mazzi et al. (2002), birds tend to have low heat tolerance, mainly due to cardiovascular or renal insufficiencies, including acid-base imbalance and other organic metabolic deficiencies caused by adverse environmental conditions. Thus, the management of the environmental conditions of the aviary is important to provide an appropriate thermal comfort for the birds and avoid these problems (Nääs et al., 2007). Santos et al. (2012) also reported that acclimatization issues cause serious problems to broilers, suggesting that the use of simple methodology for thermal diagnosis, mainly observing the aviary structures and broilers density, can help to avoid possible troubles.

Birds housed in the conventional aviary presented a higher average surface temperature (Table 3), representing a great body heat accumulation and, consequently, less efficiency on heat exchange with the environment. In addition, it was observed that, regardless of the aviary model used in the Amazon rainforest, the average surface temperature values of the birds were above the normal, around $41^{\circ} \mathrm{C}$ (Santos et al., 2012). 
Table 3 - Average surface temperature of broilers housed in two models of aviary installed in different conditions of the Amazon rainforest

\begin{tabular}{lc}
\hline Aviary model & Temperature $\left({ }^{\circ} \mathbf{C}\right)$ \\
\hline Conventional & $52.59^{\mathrm{a}}$ \\
Alternative & $43.84^{\mathrm{b}}$ \\
p-value & $0.01^{\star}$ \\
$\mathrm{CV}(\%)$ & 1.79 \\
\hline
\end{tabular}

Note: $\mathrm{CV}=$ Coefficient of variation. ${ }^{\star}$ Significant effect $(p \leq 0.01)$.

According to Moura (2001), when the environmental temperature is below or above the average body temperature, the efficiency of heat exchange decreases, characterizing a thermal stress situation (Damasceno et al., 2017). From this, the main mechanism to heat loss becomes the process of water evaporation by the respiratory system, where higher vapor pressure of the environment tends to cause greater difficulty in releasing heat through evaporative ways.

The increase on respiratory movements on the birds becomes efficient only when the relative air humidity is below $80 \%$, a situation that is not verified in the Amazonian environment, where the relative humidity normally is above $80 \%$ along the year (Villa Nova et al., 1976; Monteiro et al., 2014). Simmons et al. (1997) also reported that although the air velocity does not affect total heat loss, the increase on air velocity can cause a substantial change in heat loss mechanisms when birds are subjected to temperatures between 29.5 and 35 ${ }^{\circ} \mathrm{C}$. It is important to mention that the conventional aviary model usually uses forced ventilation as its main mechanism to provide a better heat dissipation in the environment. However this is not enough to cause an ideal condition of thermal comfort, and other points also need attention, such as the vegetation around the aviary.

When birds present a large accumulation of body heat, such as observed in the results of this study, evaporative exchanges may be not effective in heat loss, causing a negative effect on the birds due to thermal stress (Santos et al., 2012). Several studies also reported that some environmental factors related to climate and facilities are primordial to support the animals, as well as to determine their ability to respond to the environmental stimuli (Silva e Vieira, 2010; Santos et al., 2012).

According to Al-Ajeeli et al. (2018), the use of alternative models of aviary in the global poultry industry is an interesting trend, once it brings efficiency together with animal welfare standards, besides the low cost and great focus on adaptations of facilities' dimensions according to the environmental conditions. This growing concern with the birds welfare has led to drastic and mandatory changes in housing systems and aviary models around the world, especially in the USA and in the European Union (Hannah et al., 2011), making Brazil to also adapt to this world market trend (Al-Ajeeli et al., 2018).

\section{Conclusion}

The results of this study indicate that in the environmental conditions of the Amazon rainforest, the alternative aviary model, with natural ventilation, higher ceiling height and a lot of vegetation around it, provides a better condition of welfare to broilers, with low concentration of body heat and the possibility of better heat exchange with the environment.

\section{References}

Abreu VMN, Abreu PG. Os desafios da ambiência sobre os sistemas de aves no Brasil. R Bras Zootec. 2011;40:1-14.

Al-Ajeeli MN, Miller RK, Leyva H, Hashim MM, Abdaljaleel RA, Jameel $Y$, et al. Consumer acceptance of eggs from Hy-Line Brown layers fed soybean or soybean-free diets using cage or free-range rearing systems. Poult Sci. 2018;97(5):1848-51.

Bueno L, Rossi LA. Comparação entre tecnologias de climatização para criação de frangos quanto a energia, ambiência e produtividade. Rev Bras Eng Agríc Ambient. 2006;10(2):497-504. 
Cavalcanti IFA, Ferreira NJ, Silva MGAJ, Dias MAFS. Tempo e Clima no Brasil. São Paulo: Oficina de Textos; 2009. 464 p.

Cruz FGG, Rufino JPF, Melo RD, Feijó JC, Damasceno JL, Costa APGC. Perfil socioeconômico da avicultura no setor primário do estado do Amazonas, Brasil. Rev Agro Amb. 2016;9(2):371-91.

Cunningham JG. Tratado de fisiologia veterinária. Rio de Janeiro: Guanabara Koogan; 2004. 596 p.

Damasceno FA, Cassuce DC, Abreu LHP, Schiassi L, Tinôco IFF. Effect of thermal environment on performance of broiler chickens using fuzzy modeling. Rev Ceres. 2017;64(4):337-43.

Hannah JF, Wilson JL, Cox NA, Cason JA, Bourassa DV, Musgrove MT, et al. Comparison of shell bacteria from unwashed and washed table eggs harvested from caged laying hens and cage-free floor-housed laying hens. Poult Sci. 2011;90(7):1586-93.

Kolb E. Fisiologia veterinária. Rio de Janeiro: Guanabara Koogan; 1984. 612 p.

Lavor CTB, Fernandes AAO, Sousa FM. Efeito de materiais isolantes térmicos em aviários no desempenho de frango de corte. Rev Ciên Agron. 2008; 39(2): 308-16.

Lopes JCO, Ribeiro MN, Lima VBS. Estresse por calor em frangos de corte. Rev Eletr Nutritime. 2015;12(6):4478-87.

Mazzi CM, Ferro MIT, Coelho AAD, Savino VJM, Macari M, Ferro JA, et al. Effect of heat exposure on thethermoregulatory responses of selected naked neck chickens. Arq Bras Med Vet Zootec. 2002;54(1):35-41.

Monteiro JCR, Aride PHR, Oliveira AT, Santos SM, PantojaLima J, Heyer LF. Descrição da temperatura e umidade relativa do ar em diferentes localidades no bairro do Parque Dez - Manaus/AM. Biota Amaz. 2014;4(2):20-27.
Moura DJ. Ambiência na avicultura de corte. In: Silva IJO. Ambiência na produção de aves em clima tropical. Piracicaba: FUNEP; 2001. p. 75-149.

Nääs IA, Miragliotta MY, Baracho MS, Moura DJ. Ambiência aérea em alojamento de frangos de corte: poeira e gases. Eng Agríc. 2007;27(2):326-35.

Nascimento GR, Nääs IA, Baracho MS, Pereira DF, Neves DP. Termografia infravermelho na estimativa de conforto térmico de frangos de corte. Rev Bras Eng Agríc Ambient. 2014;18(6):658-63.

Richards SA. The significance of changes in the temperature of the skin and body core of the chicken in the regulation of heat loss. J Physiol. 1971;216(1):1-10.

Santos MJB, Rabello CBV, Pandorfi H, Torres TR, Santos PA, Camelo LCL. Fatores que interferem no estresse térmico em frangos de corte. Rev Eletr Nutritime. 2012;9(3):1779-86.

Silva IJO, Vieira FMC. Ambiência animal e as perdas produtivas no manejo pré-abate: o caso da avicultura de corte brasileira. Arch Zootec. 2010;59(R):113-31.

Simmons JD, Lott BD, May JD. Heat loss from broiler chickens subjected to various wind speeds and ambient temperatures. Appl Eng Agric. 1997;13(5):665-9.

Tinôco IFF. Avicultura industrial: novos conceitos de materiais, concepções e técnicas construtivas para galpões avícolas brasileiros. Rev Bras Cienc Avic. $2001 ; 3(1): 1-26$.

Villa Nova NA, Salati E, Matsui E. Estimativa da evapotranspiração na bacia amazônica. Acta Amaz. 1976;6(2):215-28. 